\title{
Geraldine Harris
}

\section{Double Acts, Theatrical Couples, and Split Britches' 'Double Agency'}

\begin{abstract}
In 2001 Split Britches presented a double bill entitled Double Agency, consisting of one new piece, Miss Risqué, and one already in their repertoire, It's a Small House and We've Lived in it Always - both works having been created in collaboration with the Clod Ensemble. In this article, Geraldine Harris re-stages her earlier encounter with Small House, in the light of seeing it again as part of the double bill, as a means of examining a number of issues concerning the work of Split Britches in general and its reception in the academic world. Particular consideration is given to the manner in which Peggy Shaw and Lois Weaver's performances have been read in terms of their 'real' lives and relationship and the various ways in which this may reflect the preconceptions of the spectator-critic. Focusing on how their work reiterates specific theatrical traditions and conventions, Harris suggests that utopian tendencies in academic feminist criticism may have underplayed the ways in which, like many famous theatrical double acts, Split Britches constantly perform on the border - between tragedy and comedy, optimism and despair, fantasy and the possible, escape and entrapment. Geraldine Harris is a Senior Lecturer in Theatre Studies at Lancaster University. Her previous publications include a number of articles on female practitioners in nineteenth-century French popular theatre and on gender issues in contemporary performance. Her latest book, Staging Femininities, Performance and Performativity (Manchester University Press, 1999), explored the relationship between feminist performance and a range of postmodern and poststructuralist theories.
\end{abstract}

IN MAY 2001, at the Nuffield Theatre, Lancaster, Split Britches offered a double bill entitled Double Agency, consisting of a new piece, Miss Risqué, and one already in their repertoire, It's a Small House and We've Lived in it Always (Small House). Both works were performed by Lois Weaver and Peggy Shaw, and created in collaboration with the Clod Ensemble, a British company whose work combines visual theatre and live music. ${ }^{1}$

In the running order of Double Agency, Small House follows Miss Risqué. However, I first saw this latter piece in Arizona in March 2000 and at that time found myself thinking that it did not seem like a 'Split Britches show'. Since then, I gather, Small House has been reworked, although to me the changes seemed more in the mood of performance than the structure and style of the piece. This is difficult to evaluate because seeing it again in my 'home' theatre, in conjunction with Miss Risqué, impacted on its effect and meaning at the point of reception in ways that forced me to re-examine my initial response.
In this article, then, I want to 're-stage' my encounters with Small House, so as to explore some issues of fantasy and reality, optimism and pessimism, within Split Britches' work and with reference to its reception within the academic world.

I find my original response embarrassing, not least because I have not actually seen all Split Britches' shows to date, although I have either read about most of them or encountered them through performance texts and video; while the ones I have seen, which include Dress Suits for Hire, Belle Reprieve, Lesbians Who Kill, and Lust and Comfort, have also featured Lois Weaver and Peggy Shaw, these, like Double Agency, were collaborations, with Holly Hughes, Bloolips, Deborah Margolin, and James Neale-Kennerley respectively. Presumably, these artists brought their differing interests, skills, and backgrounds to the works, rather undermining any notion of there being an exclusive set of characteristics that mark out a 'Split Britches show'. 
In Arizona, then, I clearly approached Small House with a set of assumptions about what a Split Britches show 'is' - and perhaps even what it 'should' be - that, as Gayatri Spivak puts it, defines the 'conditions of the possibility of hearing'. ${ }^{2}$ Without question, these assumptions were informed by what Gill Davis calls 'the preconceptions of the discourse of the academy'; and Small House does not immediately lend itself to be read in terms of the lesbian and feminist theories of subjectivity and identity, resistance and subversion, that have largely circulated around this company. ${ }^{3}$

\section{Academic Preconceptions}

In her review article 'Goodnight Ladies: on the Explicit Body in Performance', Davis cites works by Split Britches as being part of a 'small and mostly American' feminist 'canon', within which 'texts are chosen for the extent to which they embody current theoretical issues'. ${ }^{4}$ She argues that in contradiction to its own political aims, feminist writing on these 'canonical' performances can construct them as fetishized commodities, circulating as tokens of exchange within the academy as part of an 'academic colonization of performance'. ${ }^{5 .}$ In response, Davis argues for 'an openness to new performances on their own terms, whether or not they "fit" academic preconceptions'. ${ }^{6}$

Despite the theoretical nature of some of my own publications, I am in sympathy with much of this argument. However, I would caution that there is no 'openness' or access to performance that is not filtered through 'preconceptions', which are always 'theoretical' in so far as they depend on discourses concerning social reality and the relationship between performance and that 'reality'. In short, as Sue-Ellen Case remarks in her introduction to the Split Britches anthology, there is no such thing as 'simple description'. ${ }^{7}$ None the less, she also acknowledges that some of the academic debates produced around Split Britches might seem to have 'moved quite a distance from the actual performances' ${ }^{8}$

Case then opens a discussion that 'hopefully leads back to the plays and perform- ances themselves', ${ }^{9}$ differentiating between the contributions made by Shaw, Weaver, and Margolin to Lesbians Who Kill in an attempt to evaluate the differing 'performance and textual practice [with which] "lesbian" is aligned' ${ }^{10}$ Yet this argument depends on Case knowing that, unlike Shaw and Weaver, Margolin, who does not appear in the show, is not a lesbian. This is not something that could be read off the text or performance unless, in contradiction to her stated intention, Case is arguing that some parts of the text/show are clearly legible as 'lesbian' and others are not.

It is not my aim to enter this debate with Case and my doing so would be inappropriate since, like Margolin, I am not identified as a lesbian. Rather, my point is that like many commentators on Split Britches, Case's analysis is informed by intelligence concerning the 'off-stage' lives of the company, so that, along with Margolin's heterosexuality, discussions of these shows have often referred to Shaw and Weaver's everyday lives and 'real' relationship.

Unquestionably, Split Britches' work deliberately invites this sort of reading, and this is one of the ways in which, as a particular mode of political performance, the shows may challenge the traditional, hierarchical relationship between the 'real' and the mimetic. Yet, if the shows do contest this binary, then the 'reality' of these lives and this relationship could not necessarily be read from the actual performances, and the tendency to do so is as much the product of extratextual information disseminated among international yet 'localized', lesbian and/or feminist, academic sub-cultural group(s) as it is of the shows themselves.

As Jill Dolan, quoting Sarah Schulman, indicates in her recent article discussing works by Holly Hughes, Margolin, and Shaw, this is a 'passionate audience'.$^{11}$ Reflecting this, Dolan's essay deliberately and repeatedly uses terms like emotion, affect, desire, generosity, and romanticism; even 'love' makes an appearance, a word that also features twice on the back cover of the Split Britches anthology. Within poststructuralist, psychoanalytical paradigms, passion, desire, 
and love can never be entirely separated from narcissistic (mis)identifications, fetishization, objectification, and phantasmic projections: the very territory that Spilt Britches shows are celebrated for occupying in a transgressive and deconstructive manner. However, post-Brecht, and even during a period when supposedly the absolute difference between all dualisms, including that of rational/ emotional have been challenged, 'emotion', especially when linked with 'identification', has remained a problematic amongst those concerned with politics and performance.

\section{Presence and Charisma}

As Dolan indicates, within 'postmodern' approaches to the politics of performance, this suspicion of emotion is often related to suspicion of the performers' 'presence', which in his seminal article Philip Auslander defines as being tied up with notions of 'charisma'. ${ }^{12}$ This 'presence' is said to invite an identification either with the characters the performers represent, or with themselves, in ways that endow them with a potentially manipulative 'authority' and can implicitly reify essentialist concepts of subjectivity.

I have always found it ironic that by the time I got to see LSD (Just the High Points), Auslander's writing on the Wooster Group's 'deconstruction' of this 'presence' had helped engender such a mythic discourse around this already 'glamorous' company that they appeared to me the absolute epitome of (cool, ironic, postmodern) charismatic authority. This is not a reflection on the Wooster Group's actual work, but rather on how in this instance academic writing on the company might have reinforced (if not produced) an illusion of 'presence', and in Auslander's terms implicitly confirmed for some of the audience the 'ability to assume it could read the imprint of the actor's self back through her performance'. ${ }^{13}$

In the case of companies like Split Britches it also seems to me that academic discourse may indeed at times reflect and/or produce certain types of investments, projections, and identifications around Shaw and Weaver as performers, which in turn may have in- formed the perception of the potential of their performances to transform 'reality', in ways that do not necessarily relate to the performances themselves.

As I hope will become clear, I am very much part of Split Britches' 'passionate audience', and it is not my intention to critique discussions developed around this company by some of the finest scholars in the field. (In fact this present writing is dependent upon and implicitly assumes that scholarship.) Neither am I writing 'for' or 'against' 'presence', identification, and emotion. Rather, I am trying - as Sara Ahmed has indicated, in discussing the possibility for 'ethical encounters' within post-colonial feminism whether these encounters are textual or in person - to find a way of holding the embodied and the discursive, the emotional and the abstract, proximity and distance together, so that 'one gets close enough to others, to be touched by that which cannot simply be got across'. ${ }^{14}$

In retrospect, then, I believe my reaction to Small House in Arizona was heavily influenced by the sorts of emotional and intellectual preconceptions and investments noted above. However, at the time I would have focused on the apparent 'absence' of certain 'typical' Split Britches performance strategies. Small House seemed a very spare, stripped down work, and while (as Sue-Ellen Case notes) Split Britches have always been dedicated to 'poor' theatre in the economic, improvised, 'making-do' sense rather than the Grotowskian, this does not necessarily mean 'spare'. ${ }^{15}$ Indeed, their shows have always seemed to me to be on an epic scale, in the 'grand' rather than the Brechtian sense, although, as with much contemporary performance practice, Split Britches' work can be seen as part of a 'postmodern', Brechtian tradition.

This impression of 'epic scale' is not a matter of set design. For Lesbians Who Kill, for instance, the set consisted solely of a battered yellow car seat. Rather, the stage has always overflowed with worlds within worlds. The sets usually locate the shows physically and temporally in a fictional space where the performers exist as 'characters', 
such as a costume hire shop (Dress Suits for Hire), a car (Lesbians Who Kill), a flat (Lust and Comfort). However, there are usually also other, less material 'settings', so that Dress Suits for Hire is also sited in the world of horror fiction; Lust and Comfort within the world of The Servant, The Bitter Tears of Petra Von Kant, and a screenplay that is in the process of being written; and Lesbians Who Kill, as Peggy Phelan has pointed out, 'in your dreams', ${ }^{16}$ against the background of the 'real life' story of Aileen Wuornos, and of crime films such as The Grifters. The 'core' fictional world, then, opens up into multiple spaces, locations, and temporalities, where the 'characters' can take on and discard different personas, move between past, present, and future, and escape into fantasy scenarios or alternative realities whilst 'really' always remaining in the same place.

As this description might imply, there is always a further setting - the 'space of representation', where the show is literally taking place. This lies not only in the 'intertext' between various fictions, but also in 'the' stage as a historical institution and 'this' stage here and now. Thus, 'the'/'these' performers are often visible through the characters/personas, and the audience may be variously ignored, given a 'role', be addressed as a theatrical audience, or as this specific audience. However, for the most part this theatrical self-reflexivity is signified through the structure and style of the shows, rather than by direct reference.

This is exemplified in the way bits of set, objects, and costumes, are constantly introduced and discarded in a functional manner, remarking the status of these objects as 'props' in a game of 'dressing-up', 'let's pretend', or 'acting out', in all the meanings of the term. The concept of 'games' and/or 'acts' is also intrinsic to the structure of the shows. Sometimes, as with the 'looks like' / 'is like' sections in Lesbians Who Kill, the acts are literally games; but more often they are acts which are games played out as fantasy scenarios or through the borrowings from film and theatre.

Recognition of such intertextual references by the spectator can add to a strong sense within the 'core', physical location that these scenarios might have been enacted before but that nevertheless this present articulation of the fantasy/game and its outcome are not wholly predetermined. Sometimes one character can appear unsure as to the nature or rules of the game, or reluctant to take part, and must be 'seduced' into playing. Yet the sense of having played the games before makes this seem part of the act in the core, physical world, as indeed it is within the world of the/this stage.

Further, roles can shift in the course of the scenario, so that 'who' is exactly seducing 'whom' becomes increasingly confused. Identity, power, and desire, like time and place, are then always on the move, and the games or scenarios seldom have a definite ending but are dropped through exhaustion, distraction, or boredom. It is in these phases of transition that the differences and the confusions between the various worlds become most visible.

In purely formal terms, much of the above could apply to a number of contemporary devising companies. However, Split Britches remains distinctive in its restless, excessive enunciation of this form in relation to concrete social and political concerns, and also in the qualities of 'these' performers. Playing out these games of fantasy, power, and seduction, Shaw and Weaver appear to create a circuit of desire between the characters/ personas strong enough to spill out into the audience with physical force.

\section{'Small House' in Arizona}

That Small House seemed a more 'contained' show was not, then, because the set consisted only of two chairs, although it might relate to the lack of costume changes and the economical, tightly choreographed movement, both of which are unusual for Split Britches. The piece was structured around a series of games or acts, but the introduction of moments of distinct visual and musical punctuation made them feel more like completed episodes than is usual with this company, and gave the piece the rhythm of a slow movement. There were also 
The lone Lois Weaver in Small House.

Photo: Timothy Nunn.

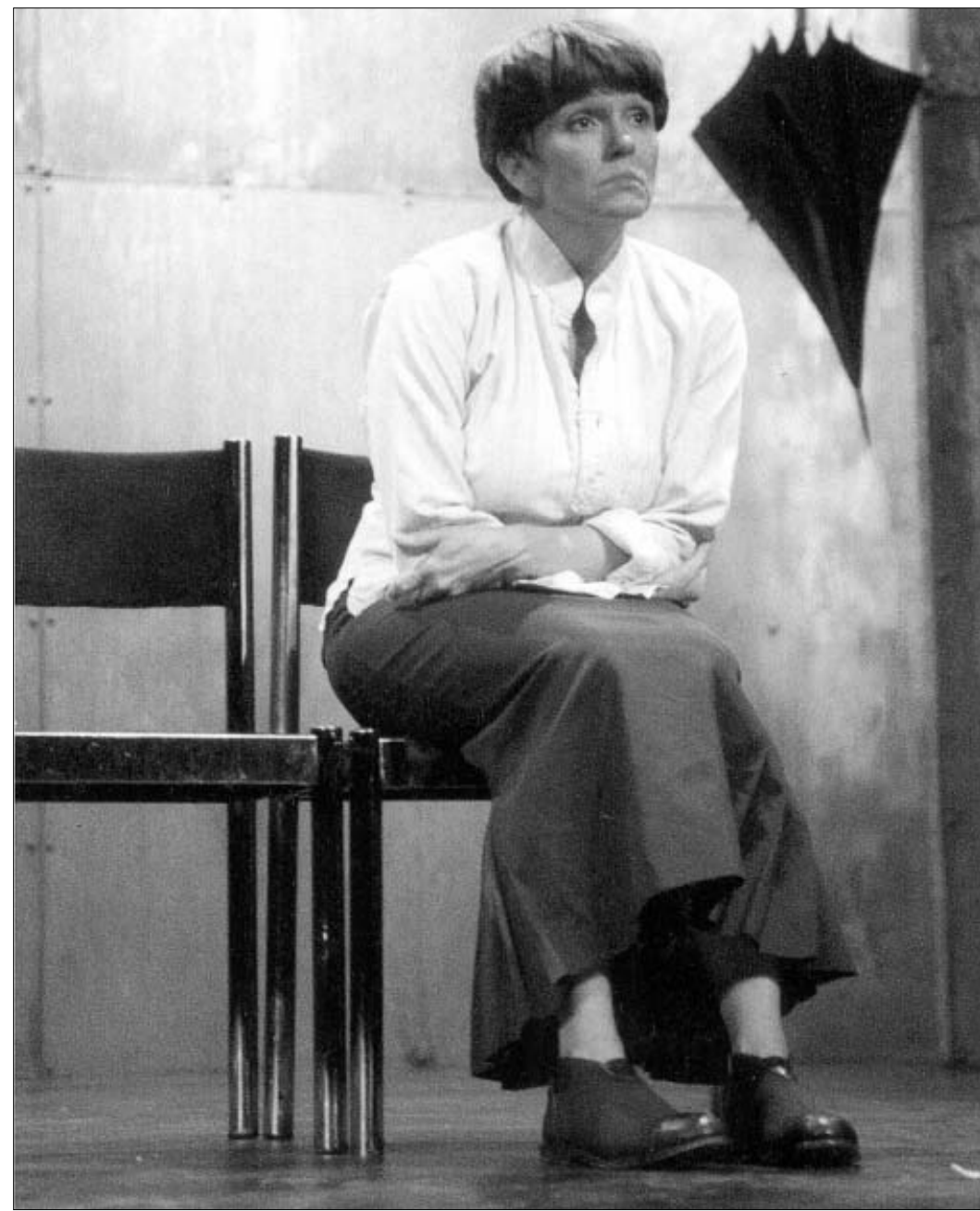

multiple settings, whereby the space was remarked as 'the small house' of the title, which was also the 'space' of the relationship between Shaw and Weaver as characters/ performers, Weaver's body/psyche, and the/ this stage. However, the 'space' for fantasy and escape and for temporal shifts appeared to have been curtailed.

Rather than 'in dreams', this show opened into a 'blues' song with the traditional 'I woke up this morning', but from then on remained firmly in the present tense. This song did develop into a flight of the imagination, where small domestic incidents such as making coffee, cracking an egg, and running a bath lead to floods, earthquakes, and other cataclysms. However, in the end it returned with a vengeance to 'everyday reality' with Shaw referring to a 'a friend ripped out of life at the age of thirty-eight', and to the fact that, 'when the American Constitution was written, ninety per cent of the population were indentured servants or slaves'.

While singing this number and for most of the succeeding 'acts', Shaw and Weaver competed for the audience's attention, literally - physically - upstaging each other. At one point Shaw slowly and clumsily spun a chair on one leg, while behind her back a grinning Weaver deftly started spinning two at the same time. At another stage, Weaver started flirting with an (imaginary?) member of the audience, winking and posing in a comic seductive manner to the accompaniment of slow jazz. At first, Shaw assumed that this 'come on' was directed at her, only realizing her error when Weaver's gestures became so grotesquely exaggerated that her 


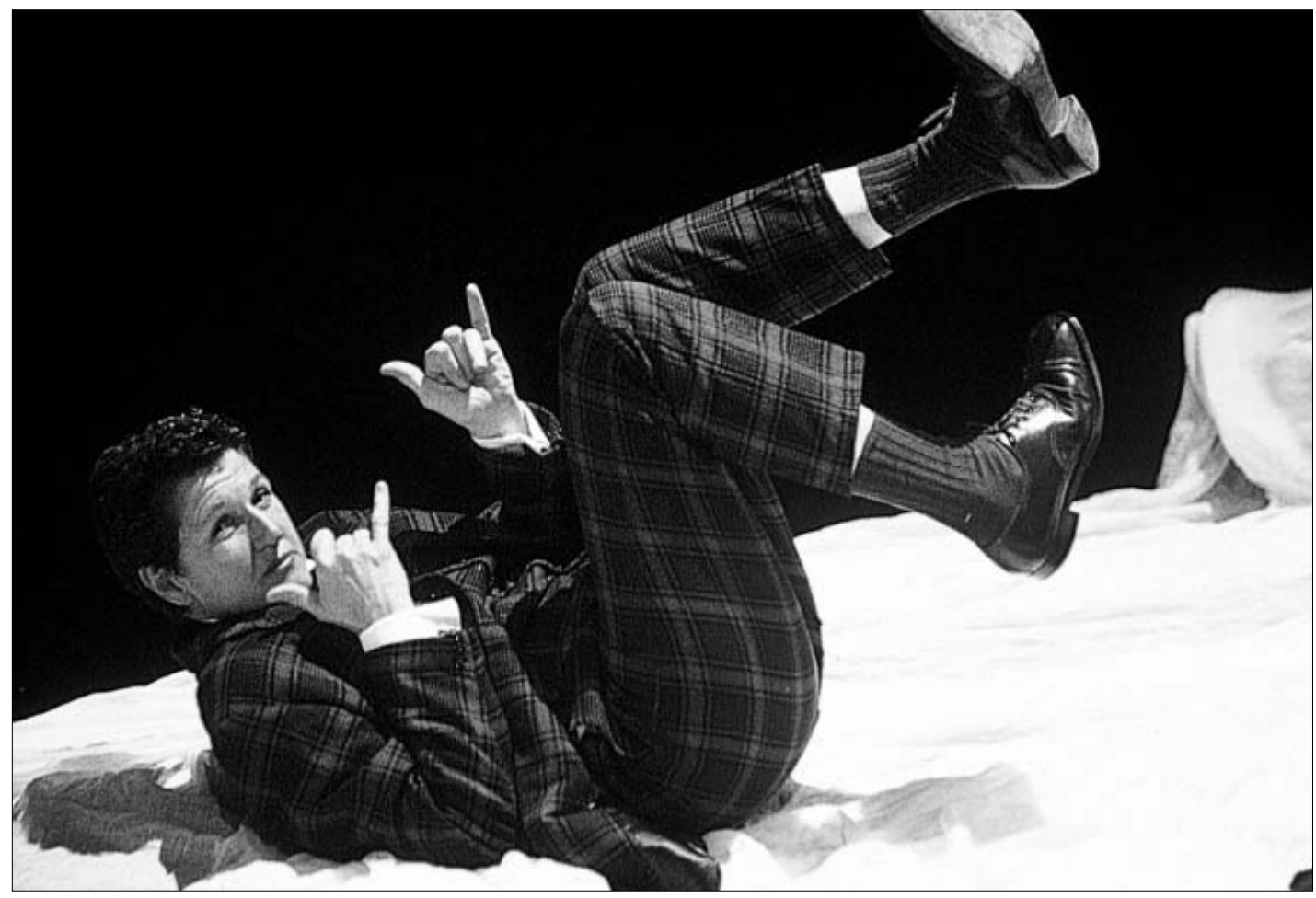

intention was unmistakable. While a kind of 'upstaging' or 'topping' of each other has always been part of Shaw and Weaver's onstage dynamic, in this instance the circuit of fantasy, power, and desire appeared no longer to be running between the characters/performers and then to the audience, but was only directed out. They each had their own side of the stage and the 'acts' or games were about distance rather than attraction, as they sulked and turned away from each other.

When they did achieve proximity, it was unsatisfactory, temporary, or more expressive of desperation than desire. Making kissing noises, Weaver persuaded Shaw over to her side of the stage and they sat cosily together until Weaver started fussing at Shaw's clothes and face, driving her away in irritation. At another point, mutually mis-timed attempts to embrace became a fight for autonomy. When Weaver sang the title song, 'We've Lived in it Always' had become 'I've Lived in it Always', and the chorus line is 'That's all very well, but I really think we should talk about me.' She also tells us that 'the gate is in need of repair and there is a crack in the wall', and that this house, overcrowded with ghosts of lovers, family, and friends clearly stands for 'her' own person, mind and body.

Later, Shaw sang of being 'so low, so low down, like at the bottom of the sea where the fish have no eyes because it's so dark', while Weaver fell asleep, waking to find that Shaw had left the stage by the scene doors. Even though Shaw had just warned that, 'If you stay in one place too long, you start living like your parents and looking like your pets', she returned and the show ended with them in the same place, in their chairs, on their different sides of the stage, silently looking over the audience's heads, as if scanning the horizon. For what? Rescue? Death?

When I first saw the piece, it struck me, despite its humour, as being about loss - the losses that come with ageing, the loss of loved ones through death, the betrayals of the body, and the slow wearing out of a relationship - and also loss of optimism in the potential for change. I was moved by this and could identify with it, but it confounded my expectations of a company, whose shows, to borrow Phelan's words on Margolin and 
Peggy Shaw (opposite page) and Lois Weaver (right) in Miss Risqué.

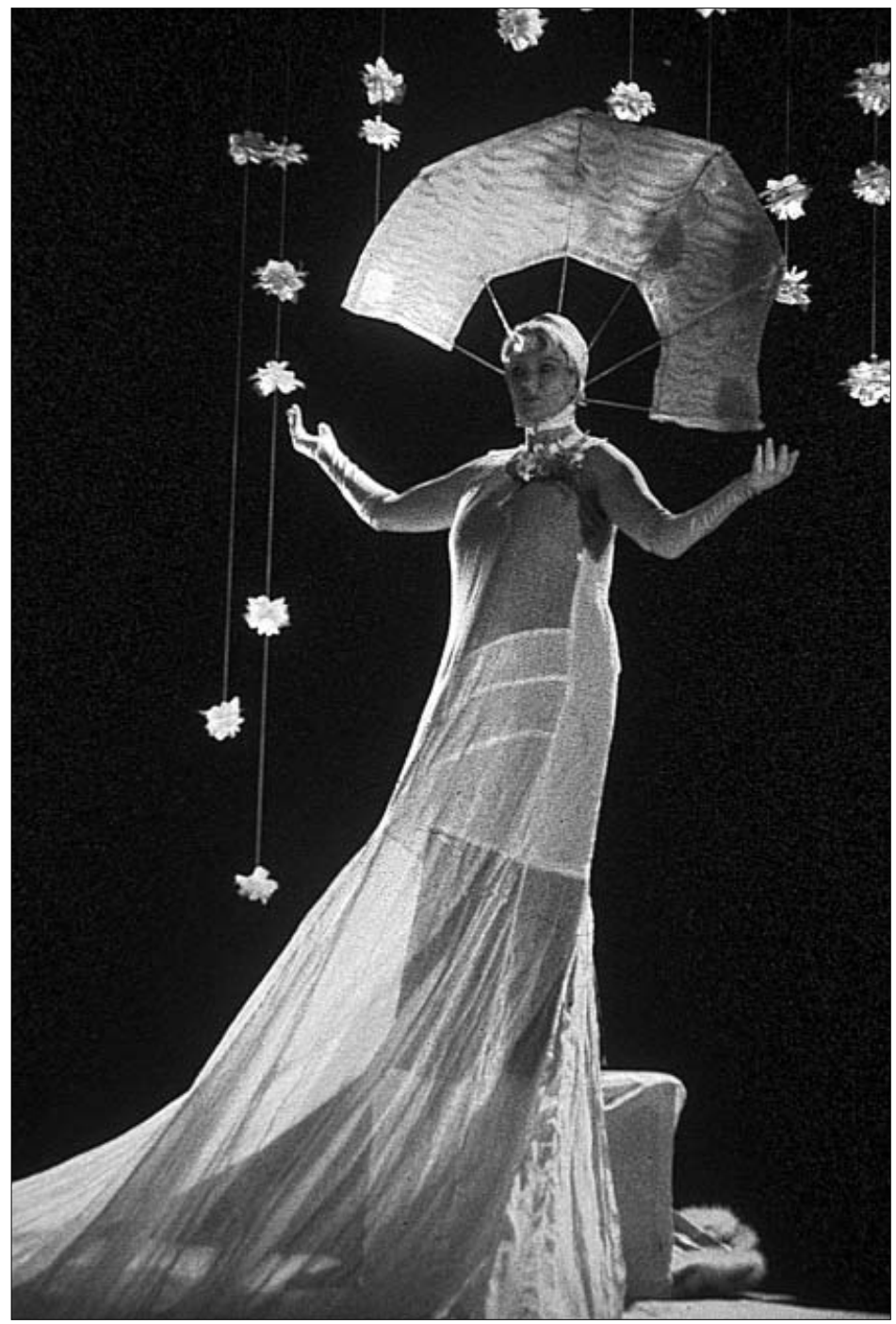

queer performance, have seemed to 'dream continually of another social space - one they help to bring into being by reciting their dreams out loud'. ${ }^{17}$ Small House left me saddened, seeming to suggest, as Case does in relation to 'Lois' and 'Peggy's' discussion of their own long-term relationship in Lust and Comfort, 'They're tired - they need a break from performing - some comfort.' ${ }^{18}$

\section{'Miss Risqué'}

This brings me to Miss Risqué, which is the piece in Double Agency on which I originally assumed I would be focusing, because, set in the French music hall of the early twentieth century, it touches directly on research I did in this field some time ago. Celebrating the music hall as a 'feminine' and 'queer' realm of seduction, fantasy, and continual selfinvention, it also better fits into my expectations of Split Britches. However, seeing the double bill made me question how much of my previous response to Small House was based on such 'preconceptions', rather than on my viewing of other Split Britches shows, or this piece itself.

Within Miss Risqué, the French music hall functions as both 'core', physical setting and as an imaginary location that opens up into 'other worlds' in ways that ultimately foreground 'the' stage as a theatrical institution. Weaver plays a star performer, Miss Risqué, and Shaw plays Casimir Serpentine, a 'spy' 


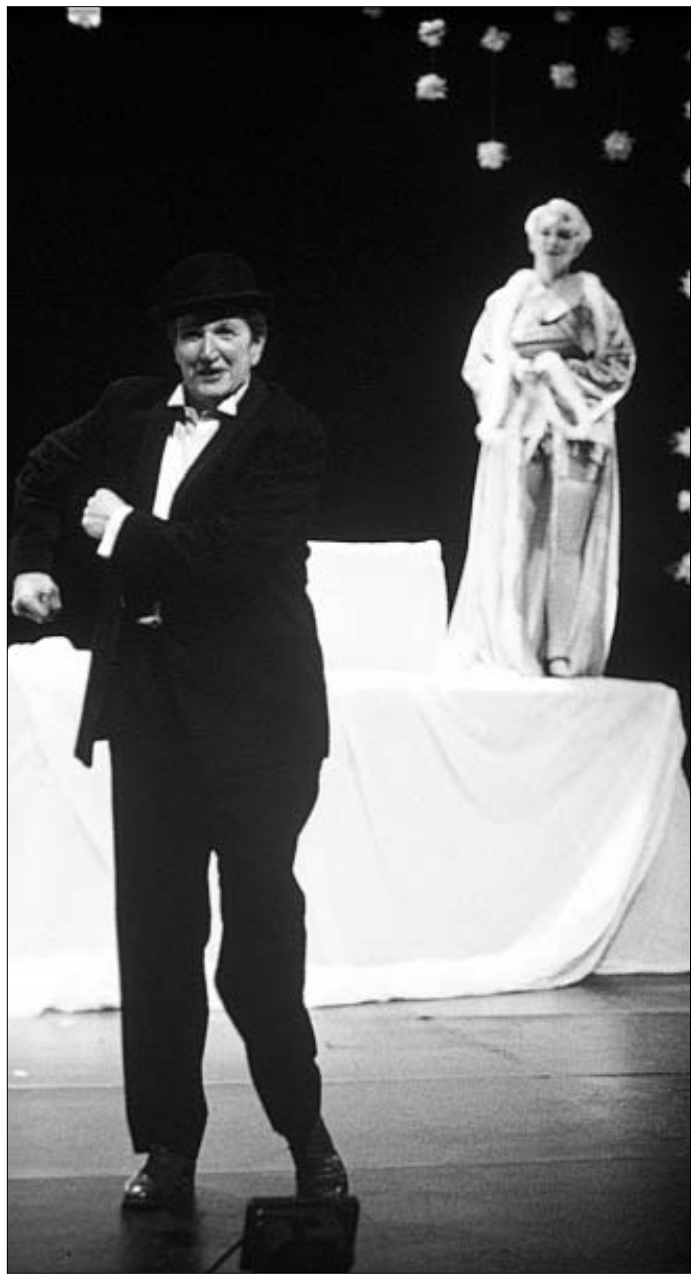

Above and opposite: celebrating the double act tradition in Miss Risqué, with Peggy Shaw as Chevalier and Lois Weaver as Mistinguett.

of uncertain gender, who infiltrates her act and is seduced into becoming her on- and off-stage partner. Amongst other sources, Miss Risqué draws on autobiographical writings by Mistinguett and Maurice Chevalier who for a period were French music hall's most famous heterosexual partnership, on and off stage - and, possibly, on the musichall memoirs of Colette, who with the cross dressing 'Yssim' ('Missy', the Marquise de Belboeuf) formed its most famous lesbian partnership on and off stage.

This may seem to be extra-textual information, but Miss Risqué certainly draws heavily on Mistinguett's memoirs in word and spirit, not least in repeating the manner in which she points out that public statements made by a performer who is Queen of Illusion do not offer any guarantee of truth or 'reality'. ${ }^{19}$ Indeed, Mistinguett simultaneously flirts with and confounds the reader's desire for the 'real' - declaring, for example, that her habit of having off-stage affairs with her onstage partners was for the good of her act because this 'give[s] the public something to think about, help[s] it find a sensuous comfort, a sort of satisfaction' ${ }^{20}$

Mistinguett claims that her relationship with Chevalier was different, and that years after the end of the affair he remained her one 'true love' (and, she indicates, vice versa). However, this is balanced by statements that 'a celebrity must be on stage all the time', and in both their writings there is a strong sense of them 'performing' the popular myth of their relationship. ${ }^{21}$ This includes a fair amount of 'upstaging' each other, with Mistinguett having the advantage of the last word by virtue of date of publication. She acknowledges and exploits, then, both the audience's desire for the 'real' even within forms dedicated to outrageous fantasy, and also the projections and fetishizations that circulate around famous theatrical couples. At the same time, both Mistinguett's memoirs and Miss Risqué underline how far such couples are always 'double agents' - their 'real' lives and identities accessible only through endless layers of illusion.

\section{Revisiting 'Small House'}

The theatrical 'French-ness' of the setting for Miss Risqué also threw into relief the American-ness of Small House. In fact, the first song of the latter locates the action geographically in North America, in part through references to specific highways and streets, but also culturally and 'mythically' through reference to the Constitution and to 'Walt Disney's proclamation that all men are created equal smashing up against the Statue of Liberty'.

The music comprised jazz and blues with 'country' influences, while the costumes were in shades of brown or 'sepia', cut to suggest the 1930s, and blue tones dominated the 
lighting. These elements, combined together with the emptiness of the stage, the emphasis on distance between the performers, and movement in straight lines or squares, recalled the art of Edward Hopper. According to Rolf Gunter Renner, 'for most Europeans Hopper's art confirms a preconceived image of America', ${ }^{22}$ so that it is not perhaps surprising that the 'American-ness' of Small House, a show made in collaboration with a British company, is more apparent on viewing it in Britain, just after a show set in theatrical Paris. All of this confirms the American-ness of the show, as 'actual' and yet entirely 'mythical', just as the relationship portrayed may be 'real' but is also wholly theatrical.

After Miss Risqué, then, Small House seemed a return to Split Britches' literal/cultural/ mythical/theatrical 'roots' in several ways. Split Britches have always drawn heavily on popular theatre traditions, but suddenly Small House seemed to invite a reading specifically in relation to famous theatrical couples in terms of the 'double act' tradition, as popularized within European music hall, and American vaudeville and cinema. This is of course, also a tradition that influenced Beckett's Waiting for Godot and early television situation comedy.

To my mortification, it was only at this point in my thinking about the show that I realized what was 'absent' in Small House. Apart from the songs, it was virtually silent, where - whatever the collaboration - Split Britches' shows, Miss Risqué included, have always contained floods of words: comic dialogue, monologues, soliloquies, passages of poetry and prose, all essential to the creation of 'epic scale' and multiple worlds. There are many reasons why I might have originally failed to register this, not least that I remember the text in Split Britches shows not as words but as vivid, visceral images. However, this was also doubtless due to the Clod Ensemble's adeptness with non-verbal theatrical languages, of the sort that have always informed 'popular' theatre.

Significantly, the stage directions for Lust and Comfort describe the final act as 'a cross between a Beckett play and contemporary

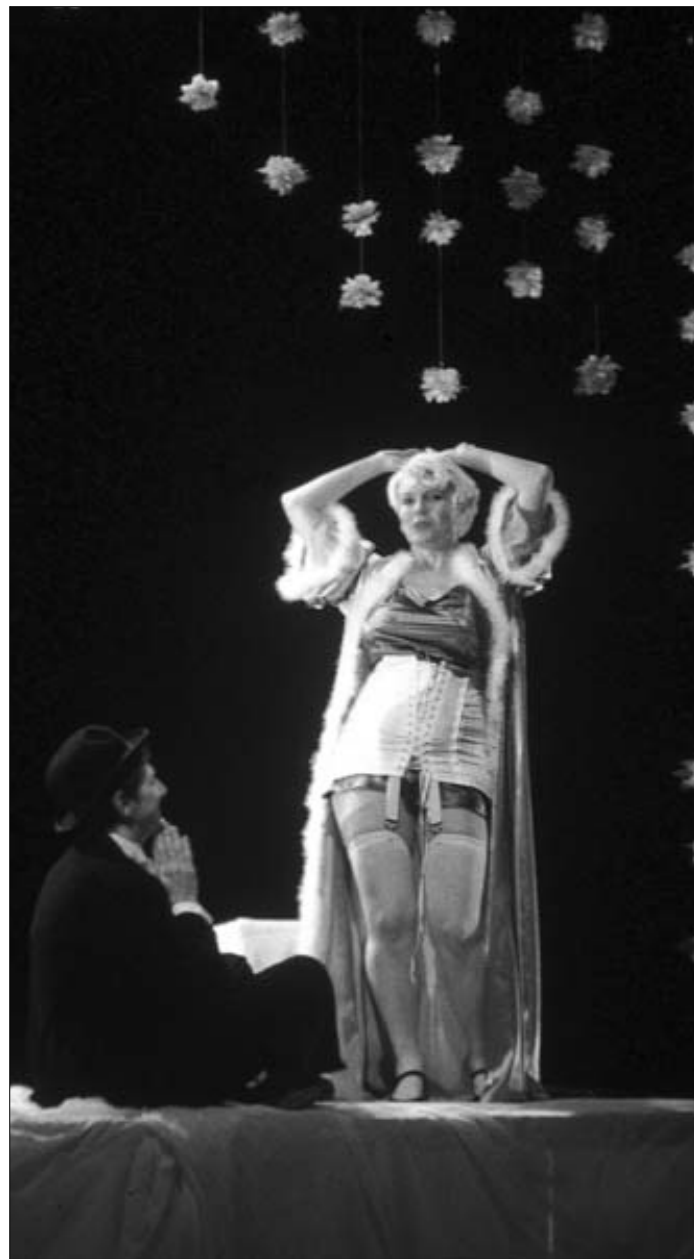

television situation comedy'.23 Equally, in classic double acts such as Laurel and Hardy, the action, as in Small House, often revolves around major disasters stemming from small domestic incidents. Further, most celebrated, male, same-sex double acts invite queer readings, although this has usually been evaded by perceiving them as standing for 'all humanity', even while simultaneously defining them as the other sorts of 'outsiders and eccentrics' that Split Britches aim to celebrate alongside queers in their shows. ${ }^{24}$

\section{Ambivalences of the Double Act Tradition}

Female, same-sex double acts are seldom accorded 'universal' status, but all double acts walk a fine line between the comic and the tragic, due mainly to the conventional dramatic structuring that informs them. Since 
it is their status as eccentrics and outsiders, combined with and directly related to their mutual interdependence, which gives them their identity, any bids for inclusion in the norm, for individual agency or change, are predetermined to be frustrated: indeed, the making of such bids is usually the key dynamic of the 'act'.

However, comic optimism wins out in most double acts, and until recently in situation comedy, due to amnesia whereby at the beginning of each act or episode characters start anew, unburdened by the memory of past disasters and so unable to foresee potential future defeats. This allows them to keep striving and keep failing in exactly the same ways. In contrast, Estragon and Vladimir can neither entirely forget nor be confident of properly remembering the past, and so in the present are alternately tantalized and paralysed by the uncertainty of the possibility for future change within which hope is as agonizing as despair.

Alongside the optimistic comment cited above, Peggy Phelan also describes queer performance practice as the product of surviving violent abjection in the world of the social. ${ }^{25}$ Although it is seldom explored, critical writing has acknowledged a 'darker' side to Split Britches' work. From Split Britches itself onwards, the relationships between the characters/performers have been ones of love, desire, and community but also a type of interdependence which, like the 'core' physical locations, renders them simultaneously a space of refuge and of entrapment. Like Vladimir and Estragon, characters/performers constantly speak of leaving the core location and each other but never do.

The games and acts in which they engage open up 'alternative worlds' but, as with Godot, are also marked as ways of passing time that offer only a temporary 'escape'. As with situation comedy, if the 'outside' breaks in, it is a threat, not a promise. If the characters/performers do not go there, it is because it is a dangerous, deadly place, the realm of those trying to steal their land (Split Britches), of little Peter (Dress Suits for Hire), of bogeymen with axes, chainsaws, knives, or guns (Lesbians Who Kill), and of shadowy govern- ment agents like those who try to strip Miss Risqué of her illusions. Haunted by traces of old scars and wounds, sometimes the 'characters' seem on the verge of despair, exhausted by the restless labour of 'acting out', sick and tired of 'making do' with the space allowed to them.

Actually, for the first time in any Split Britches show I have seen, in Miss Risqué a character leaves the space(s)/stage and does not come back. After all these years, such a leaving is abrupt, almost casual, as Serpentine/Shaw, bounces off to Hollywood with Miss Risqué/Weaver's 'Go fuck a palm tree', ringing in her/his ears. And Miss Risqué/ Weaver simply shrugs, puts on her costume, makes up another story, and goes on reinventing herself, on her stage, a performer who, as she says, may not 'have changed the world', but has 'taken up a little of its time'.

\section{Between Hope and Despair}

With the proviso that Small House is a Clod Ensemble show too, I now think of it as very much in the Split Britches' mould, despite or perhaps because of its Beckettian overtones. I think some lesbian and feminist theory of the last twenty years engendered utopian fantasies of changing the world 'performatively', in the instant manner of 'Let there be Light!' This has been at the expense of the way that Judith Butler, for instance, stresses the ambivalence of repetition, the interdependence of all subjectivity, and the uncertainty of the space for agency in the process of performativity, let alone acknowledging the economic and material relations that govern 'everyday reality'. ${ }^{26}$

In terms of performance criticism, such fantasies have accumulated around certain groups, especially those like Split Britches, whose work by sheer force of desire and imagination seems to hold out models for 'dreaming into being another social space'. However, Split Britches and their various collaborators have always worked within the pragmatic and the possible as well as through fantasy, exploiting the undecidability of repetition through re-inventions of the past in the present, in the always un- 
certain hope of producing a different sort of future.

Their shows have also, literally and metaphorically, always indicated the labour of production and the cost of such dreaming. Moreover, while they may explore the limits of the possible within the constraints of the space in which they find themselves, their shows ultimately take place within the conventions of the/this stage, whereby that which is 'outside' that space, including their real lives and relationship, may be remarked, but as a 'history which cannot be fully presented, even if it's not absent' ${ }^{27}$

After the interval in Double Agency, the double act was back together in Small House, and at times the space they inhabited still seemed stifling, so that when Shaw opened and stepped out through the fire exit at the back of the Nuffield, the audience sighed in relief as fresh night air blew in. Yet at the same time this piece offers the deeply theatrical pleasures of seeing Shaw and Weaver in a show carefully designed to exploit the skills in playing off each other and off the audience they have developed from twenty years of working together as performers.

At least twice in the show, to measured blues music, they moved upstage on their opposite sides with their backs to the auditorium and paused before turning back together, in perfect time, towards the audience. I found this moment of punctuation moving. Shaw and Weaver were 'together' and yet apart, balanced between a retreat and return, between the optimism of the double act or situation comedy as they start back into the show again, and the despair of Vladimir and Estragon as they find themselves still in the same place.

It would be easy to read Shaw and Weaver in Small House as 'everywomen', revealing 'truths' about long-term relationships, about ageing, about loss. To do so would be an act of appropriation that ignores their specificity as these particular performers, whose lives and history inform their work. Yet equally, to read this show as revealing something of Shaw and Weaver's off-stage lives and relationship is to ignore how far on stage they are also always these particular performers, whose lives and histories are available to us only through layers of fiction created (in this instance with the collaboration of Clod Ensemble) by means of their labour.

\section{Notes and References}

1. For Double Agency: Suzy Wilson (director), Paul Clarke (music), Annabel Lee (design), Aideen Malone (lighting), Hannah Leach (production and stage management), words by Peggy Shaw and Lois Weaver, performed by Peggy Shaw and Lois Weaver.

2. Gayatri Chakravorty Spivak, The Spivak Reader, ed. D. Landry and G. Maclean (London; New York: Routledge, 1996), p. 289.

3. Gill Davis, 'Goodnight Ladies: on the Explicit Body in Performance', New Theatre Quarterly, XV, No. 58 (1999), p. 187.

4. Ibid., p. 185

5. Ibid.

6. Ibid., p. 187 .

7. Sue-Ellen Case, ed., Split Britches: Lesbian Practice/ Feminist Performance (London; New York: Routledge, 1996), p. 15.

8. Ibid., p. 15 .

9. Ibid., p. 17 .

10. Ibid., p. 16

11. Jill Dolan, 'Performance, Utopia, and the "Utopian Performative",' Theatre Journal, LIII (2001), p. 478 .

12. Philip Auslander, From Acting to Performance: Essays in Modernism and Postmodernism (London; New York: Routledge, 1997), p. 62-4.

13. Ibid., p. 67 .

14. Sara Ahmed, Strange Encounters: Embodied Others in Post-Coloniality (London; New York: Routledge, 2000), p. 157 .

15. Case, Split Britches, p. 5

16. Linda Hart and Peggy Phelan, 'Queerer Than Thou: Being and Deb Margolin', Theatre Journal, XLVII, No. 2 (1995), p. 278.

17. Ibid., p. 28o.

18. Case, Split Britches, p. 34 .

19. Mistinguett, Mistinguett by Mistinguet, trans. L. Hill (London: Elek, 1954). See also Geraldine (Gerry) Harris, 'Regarding History: Some Stories Concerning the Café-Concert, the Music Hall, and the Feminist Academic', The Drama Review, XL, No. 4 (1996).

20. Mistinguett, Mistinguett, p. 242.

21. Ibid., p. 242. See also Maurice Chevalier, $M a$ route et mes chansons, Vol. 1. (Paris: Julliard, 1946).

22. Rolf Gunter Renner, Edward Hopper, trans. M. Hulse (Hamburg: Benedickt Taschen, 1990), p. 7 .

23. See text for Lesbians Who Kill, in Case, Split Britches, p. 226

24. Cited in the programme notes for Double Agency. 25. Hart and Phelan, 'Queerer than Thou', p. 280. 26. See Judith Butler, Bodies that Matter: on the Discursive Limits of 'Sex' (London; New York: Routledge, 1993).

27. Ahmed, Strange Encounters, p. 156. 